\title{
The diversity of Zooplankton in Water Area of Coal Mining as The Teaching Material
}

\author{
Bunda Halang \\ Biological Education Department \\ Universitas Lambung Mangkurat \\ Banjarmasin, Indonesia \\ bundahalang@ulm.ac.id
}

\begin{abstract}
PT. Adiabara Bansastra is a company which works in coal specific port that lies at the side of Serongga River and discards the waste to the river so the quality of the river can decrease in the future. One of the activities of local fisherman society which is often done at that river is caught fishes using the fishhook tool. Aims of this research are to determine the diversity of zooplankton in the water area of coal specific port of PT. Adiabara Bansastra in Serongga Village and to establish that water quality of that river according to their diversity indexes. The methods of this research are sampling methods which consist of three sampling points, that are: (1) sampling point at the water of the river or near the quay of the coal specific port of PT. Adiabara Bansastra, (2) sampling point at the settling pond $I$ of the coal specific port of PT.Adiabara Bansastra, and (3) sampling point at the settling pond III of the coal specific port of PT.Adiabara Bansastra. Data of the observation are analysed by using the Shannon Wiener of diversity index and the water quality of diversity index. The results of the research from the lowest to the highest zooplankton diversity indexes respectively were 0,974 (sampling 2); 1,471 (sampling point 3); and 1,829 (sampling point 1) and the water qualities of them were the criteria of light polluted (sampling point 1 ), medium polluted (sampling point 3), and heavy polluted (sampling point 2). Then, their results of this research will become a material teaching in form of the leaflet which was valid and reliable.
\end{abstract}

\section{Keywords - diversity, specific port, Serongga River}

\section{INTRODUCTION}

Environmental damages or disruptions are caused by some activities of people which is a direct or an indirect influence the ecosystems of balances, so the environmental qualities are decreased. For example, water qualities are decreased. One of the activities which are guessed can cause decreased water qualities is the activity of coal specific port. The indicator of decreased water quality is decreased abundance or diversity of zooplanktons.

Reference [1] said that the decreased diversity could be assumed as an indicator of the change of an environmental condition. The change of the environmental condition can be seen according to the organisms which be meet in that area. The organisms which are used to investigate the environmental condition named an indicator species or an organism of the population indicators. One of the population indicators is zooplankton which can be used as a biological indicator of pollution.
Reference [2] said that zooplankton had an important role that was as a primer produced at the food chain in the water ecosystem. Knowing diversity index of the zooplankton, we could determine the stabilisation of biota community or water quality what the water was a heavy polluted or a moderate polluted or light polluted or not polluted. The abundance of zooplankton in water determined the fertility of zooplankton so the zooplankton could be used as a kind of the bioindicator of water environmental condition. The degrading indicator of water environmental condition was the degradation of the abundance or diversity of the zooplankton.

\section{METHOD}

The tools which were used to take the zooplankton samples were a plankton net numbers of 25 and several tools which were used to make the water samples, such as bottles of samples and the other. The methods were used in this research were descriptive qualitative and quantitative methods. Taking of the data were done directly by observing to the field. This research was located at the Serongga River in Kotabaru Regency. The procedures of this research were to observe the location of research, prepared the tools and materials. Established sampling points which consisted of three sampling points, that were : (1) sampling point at the water of the river near the quay of the coal specific port of PT. Adiabara Bansastra, (2) sampling point at the settling pond I of the coal specific port of PT.Adiabara Bansastra, and (3) sampling point at the settling pond III of the coal specific port of PT.Adiabara Bansastra. Next, took zooplankton samples by using the plankton net number 25 in certain water deep. Then those samples were entered into bottles of samples. Then, those samples were given a label of each the location of sampling points as well as recorded each of them. Those samples which found in the field were collected for counting the zooplankton and then they were analyzed by using the Shannon Wiener of the formula, diversity index which is from reference [2], Some of the environmental parameters were measured and the water quality of the Serongga River is established according to the criteria:

- Diversity Index $>2,0$ : The water is not polluted

- Diversity Index between 1,6-2,0: The water is light polluted

- Diversity Index between $1,0-1,5$ : The water is moderately polluted 
- Diversity Index $<1$ : The water is heavily polluted

\section{RESULT AND DISCUSSION}

The species or taxa which found the research area consisted of eight taxa or species. Seven of them were :
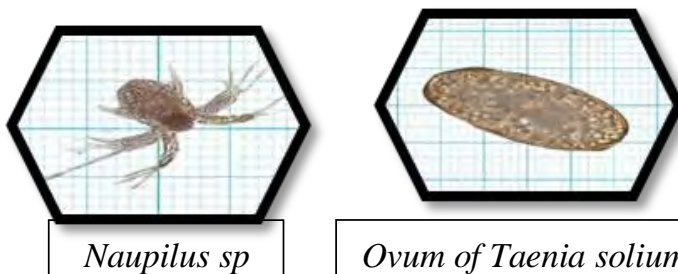

Naupilus $s p$

Ovum of Taenia solium
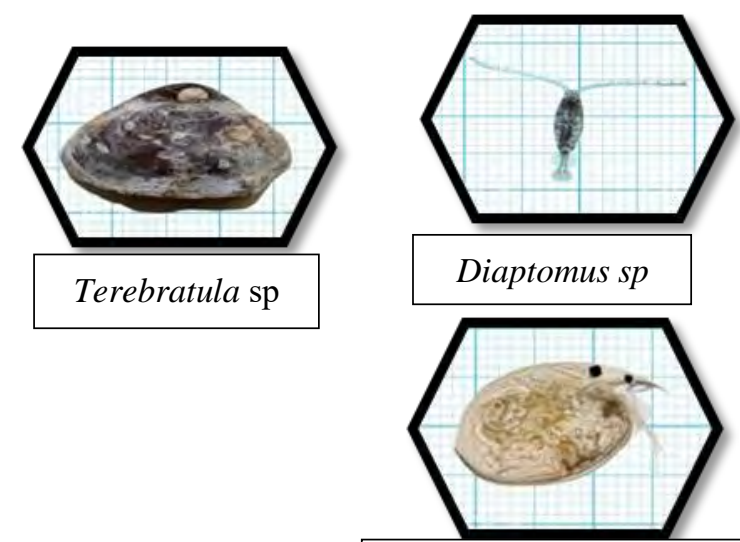

Chydorus sphaericus

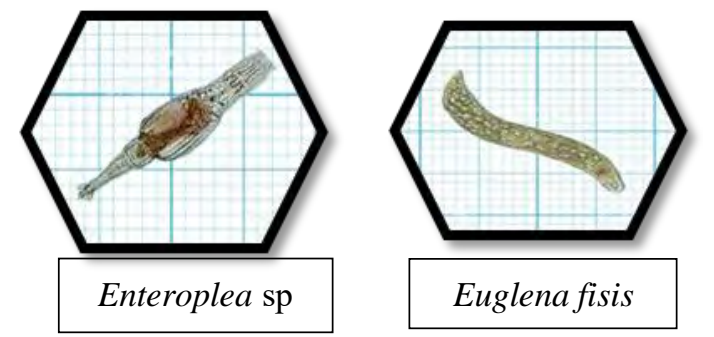

Fig. 1. The species of zooplantons

TABLE I. LISTS OF THE ABUNDANCES (NP) OF THE ZOOPLANKTONS AT THE RESEARCH AREA

\begin{tabular}{|c|l|l|l|}
\hline \multirow{2}{*}{ Taxa } & \multicolumn{3}{|c|}{ Abundance of Sampling Site (cells/L) } \\
\cline { 2 - 4 } & \multicolumn{2}{|c|}{$\mathbf{1}$} & \multicolumn{1}{c|}{$\mathbf{2}$} \\
\hline $\begin{array}{c}\text { Ovum of Taenia } \\
\text { solium }\end{array}$ & 8.02 & - & 31.25 \\
\hline Naupilus sp & 9.09 & 11.86 & 1.56 \\
\hline Terebratula sp & 12.30 & 18.27 & - \\
\hline Diaptomus sp & 1.60 & 2.03 & 17.97 \\
\hline Chydorus sphaericus & 24.06 & - & 1.56 \\
\hline Enteroplea sp & - & 1.02 & 13.28 \\
\hline Enterpina sp & - & - & 47.66 \\
\hline Euglena fisis & - & - & 4.69 \\
\hline Total & 55.07 & 32.99 & 123.27 \\
\hline
\end{tabular}

Notation:

- Sampling 1: The sampling point at the water of the river near the quay of the coal specific port of PT.Adiabara Bansastra

- Sampling 2: The sampling point at the settling pond I of the coal specific port of PT.Adiabara Bansastra

- Sampling 3: The sampling point at the settling pond III of the coal specific port of PT.Adiabara Bansastra.

The diagram of the zooplanktons can be seen in figure 2 below:

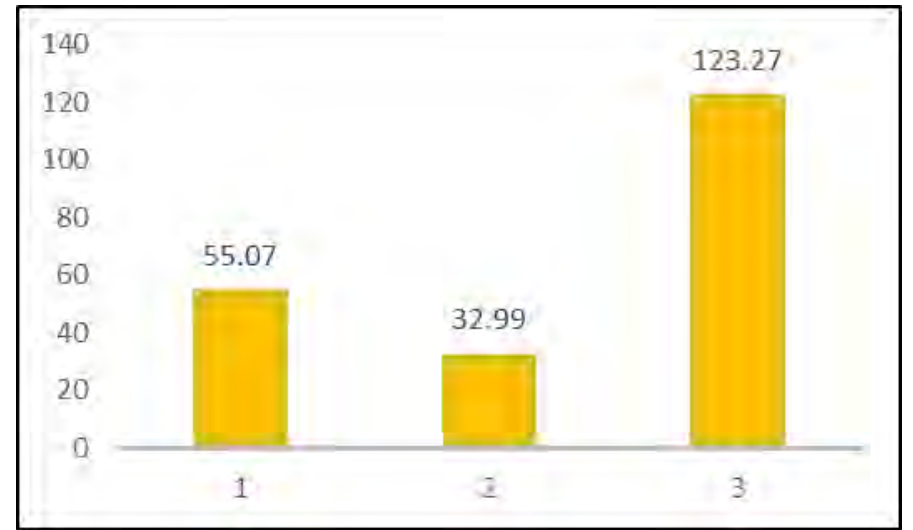

Fig. 2. Diagram of zooplankton abundances

TABLE II. LISTS OF THE DIVERSITY INDEX OF THE ZOOPLANKTONS AT THE RESEARCH AREA

\begin{tabular}{|c|l|l|l|}
\hline \multirow{2}{*}{ Taxa } & \multicolumn{3}{|c|}{ Diversity Index of Sampling } \\
\cline { 2 - 4 } & \multicolumn{1}{|c|}{$\mathbf{2}$} & \multicolumn{1}{c|}{$\mathbf{3}$} \\
\hline Worm Larvae & 0.248 & - & 0.348 \\
\hline Naupilus $\boldsymbol{s p}$ & 0.265 & 0.368 & 0.055 \\
\hline Terebratula $\boldsymbol{s p}$ & 0.305 & 0.327 & - \\
\hline Diaptomus $\boldsymbol{s p}$ & 0.086 & 0.172 & 0.281 \\
\hline Chydorus sphaericus & 0.367 & - & 0.055 \\
\hline Enteroplea $\boldsymbol{s p}$ & - & 0.107 & 0.240 \\
\hline Enterpina $\boldsymbol{s p}$ & - & - & 0.367 \\
\hline Euglena fisis & - & - & 0.124 \\
\hline Total & 1.271 & 0.974 & 1.471 \\
\hline
\end{tabular}

\section{Notation:}

- Sampling 1: The sampling point at the water of the river near the quay of the coal specific port of PT.Adiabara Bansastra

- Sampling 2: The sampling point at the settling pond I of the coal specific port of PT.Adiabara Bansastra,

- Sampling 3: The sampling point at the settling pond III of the coal specific port of PT.Adiabara Bansastra.

The diagram of zooplankton diversities can be shown in figure 3. 


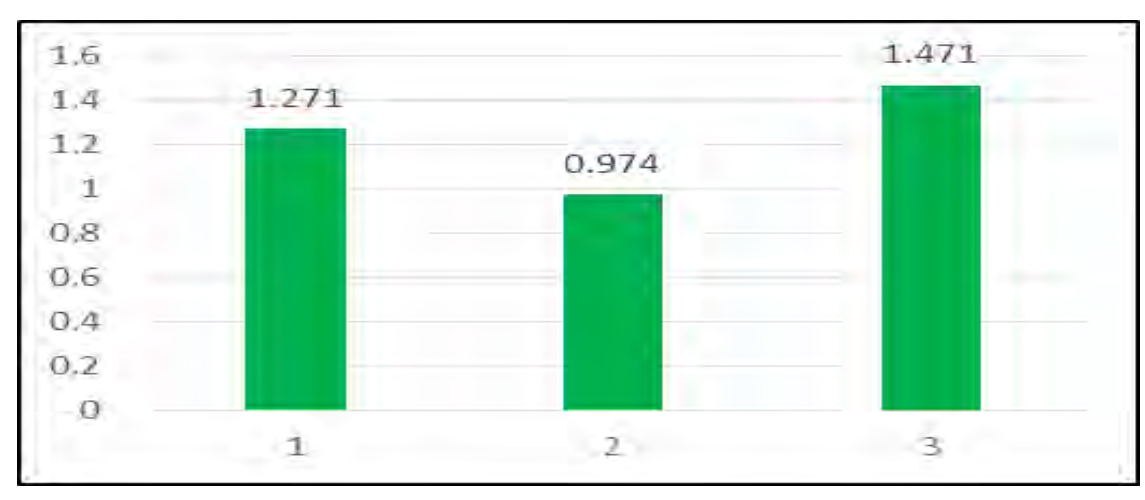

Fig. 3. Diagram of zooplankton index diversities

TABLE III. THE VALUE OF THE ENVIRONMENTAL PARAMETERS AT THE SERONGGA RIVER IN KOTABARU

\begin{tabular}{|c|c|c|c|c|c|c|}
\hline \multirow{2}{*}{ Parameters } & \multirow[t]{2}{*}{ Unit } & \multicolumn{3}{|c|}{ Results of Samplings } & \multirow{2}{*}{$\begin{array}{l}\text { Maximum } \\
\text { Quality } \\
\text { Standard }\end{array}$} & \multirow[t]{2}{*}{ Quality standard $* * *$} \\
\hline & & Sampling 1 & $\begin{array}{c}\text { Sampling } \\
2\end{array}$ & $\begin{array}{r}\text { Sampling } \\
3 \\
\end{array}$ & & \\
\hline \multicolumn{7}{|c|}{ Physics } \\
\hline Temperature & ${ }^{\circ} \mathrm{C}$ & 27,4 & 27,7 & 27,9 & $38^{*}$ & Deviasi 3 \\
\hline Color & $\mathrm{mg} / \mathrm{l}$,PtCo & 15,5 & 64,6 & 43,5 & & \\
\hline Turbidity & NTU & 23,4 & 24,0 & 99,7 & & \\
\hline Total dissolved solid & $\mathrm{mg} / \mathrm{l}$ & 12.800 & 722 & 14.200 & $2000^{*}$ & 1000 \\
\hline Total suspended solid & $\mathrm{mg} / \mathrm{l}$ & 28 & 30 & 46 & 200 & 50 \\
\hline \multicolumn{7}{|c|}{ Chemics } \\
\hline$p H$ & - & 4,07 & 4,31 & 6,15 & $6-9$ & $6-9$ \\
\hline Dissolved Oxygen & $\mathrm{mg} / \mathrm{l}$ & 5,17 & 5,74 & 5,37 & $4 * *$ & 4 \\
\hline Biological Oxygen Demand & $\mathrm{mg} / \mathrm{l}$ & 2,42 & 2,76 & 3,12 & $50^{*}$ & 3 \\
\hline Chemical Oxygen Demand & $\mathrm{mg} / \mathrm{l}$ & 28,9 & 29,2 & 34,1 & $100^{*}$ & 25 \\
\hline Sulphate, SO4 & $\mathrm{mg} / \mathrm{l}$ & 542 & 142 & 551 & $(-)^{* *}$ & $(-)$ \\
\hline PO4-P & $\mathrm{mg} / \mathrm{l}$ & 0,036 & 0,043 & 0,038 & $0,2^{*}$ & 0,2 \\
\hline $\mathrm{Fe}$ & $\mathrm{mg} / \mathrm{l}$ & 0,308 & 0,683 & 0,199 & 7 & $(-)$ \\
\hline$P b$ & $\mathrm{mg} / \mathrm{l}$ & 0,009 & 0,11 & 0,007 & $0,1^{*}$ & 0,3 \\
\hline $\boldsymbol{C d}$ & $\mathrm{mg} / \mathrm{l}$ & 0,011 & 0,012 & 0,010 & 0,05 & 0,1 \\
\hline
\end{tabular}

Notation :

\section{A. Sampling Site:}

- Sampling 1: The sampling point at the water of the river near the quay of the coal specific port of PT.Adiabara Bansastra, with coordinate point : $\mathrm{S}: 03^{0} 12^{\prime} 00.9^{\prime}, \mathrm{E}$ : $116^{0} 03^{\prime} 40.4^{\prime \prime}$

- Sampling 2: The sampling point at the settling pond I of the coal specific port of PT.Adiabara Bansastra, with coordinate point : $\mathrm{S}: 03^{0} 12^{\prime} 00.1^{\prime}, \mathrm{E}: 116^{0} 03^{\prime}$ $38.9^{\prime}$

- Sampling 3: The sampling point at the settling pond III of the coal specific port of PT.Adiabara Bansastra, with coordinate : $\mathrm{S}: 03^{0} 11^{\prime} 59.0^{\prime}, \mathrm{E}: 116^{0} 03^{\prime} 46.7^{\prime}$

\section{B. Quality Standards:}

\section{1) Wastewater}

- Governor Regulation of South Kalimantan of the number of 036 of 2008 about the exchange of Governor
Regulation of South Kalimantan of the number 04 of 2007 about the Standard Quality of Wastewater at Industrial Activity, Hotel, Restaurant, Hospital, Domestic, and Mining.

- *Governor Regulation of South Kalimantan of the number 04 of about the Standard Quality of Wastewater at Industrial Activity, Hotel, Restaurant, Hospital, Domestic dan Mining.

- . ** Government regulation of the number of 82 of 2001 about the Management of Water Quality and Water Pollution Control (Class II).

\section{2) Water River}

- *** Governor Regulation of South Kalimantan number 05 of 2007 about Quality Standard of River (class II)

According to the description of the zooplanktons at the Serongga River in Kotabaru were found that there were eight species of the zooplanktons in the three locations of sampling points. These species were Naupilus sp, ovum of Taenia saginata, Terebratula sp, Diaptomus sp, Chydorus sphaericus, 
Enteroplea sp, dan Euglena fisis. The species of zooplanktons which were in location 1 were 5 species. There were 4 species in the location of sampling point 2, and there were 7 species in the location of sampling point 3 . These indicated that the water of Serongga River and it's around were less supportive of zooplankton life. The factors which support the zooplankton life were nutrients less available in this location. Increasing nutrient style indicated increasing zooplankton population and decreasing nutrients caused decreasing zooplankton population [3].

According to the results of this research were found that the zooplanktons which were the most abundances were the zooplanktons which be found in the location of sampling point $3(123,27$ cells / $)$. Whereas the lowest abundances of zooplanktons were found in the location of sampling point 2 $(32,99$ cells/l). All of the zooplankton abundances which found at the three locations of sampling points were low abundances. These were caused by one of the zooplankton foods were phytoplanktons. The phytoplanktons which were found in this area were only a few zooplaanktons [4].

If diversity of biota was very low from its optimum, the young biota which could tolerate it was very little [5][6]. Next, they said that to measure biology conditions were the manner which was very well to evaluate the quality of freshwater ecosystems [6][7].

Biology indicators can be used to know environmental degradation and water quality [8]. The high concentrations from trace elements which were dissolved in basic water and surface water were the one main problem related to acid drainage which is produced by mining area of sulfides and coals [9].

There are manners which are used to establish the criterion of water quality. One of them is the criterion of water quality of biologically. Water qualities can be established according to their diversity indexes. The water quality at the sampling points 1 and 3 were moderately polluted because their diversity indexes respectively were 1,271 and 1,471. Whereas the water quality at the sampling point 2 was heavy polluted because its diversity index was 0,974 .

The water qualities were moderate to heavy polluted because the total dissolved solids (TDS) concentrations of sampling points 1 and 3 were $12.800 \mathrm{mg} / \mathrm{l}$ and $14.200 \mathrm{mg} / \mathrm{l}$ according to the results of this research. The high value of these TDS was assumed because runoff which brought land or wastewater into river or settling pond contains some small particles. These are appropriate with the statement that the exchange of TDS concentration can disturb biota in water because it changed the salinity, composition of the ion-ion, and the toxicity of ion-ion [11][12].

The water qualities were polluted because of the high value of sulphate $\left(\mathrm{SO}_{4}\right)$ at all of the sampling points. The value of the $\mathrm{SO}_{4}$ at the sampling points 1,2 , and 3 respectively were
$542 \mathrm{mg} / 1,142 \mathrm{mg} / 1,551 \mathrm{mg} / \mathrm{l}$. The high values of the $\mathrm{SO}_{4}$ were assumed because there were the activities of the coal specific port which its waste fall into the water and its around. Coals contained a variation of some elements or compounds, some of them were $\mathrm{SO}_{4}$ and the others [11].

\section{CONCLUSION}

- Diversity Indexes of the zooplanktons from all of the observed sampling points in water of coal specific port area of PT. Adiabara Bansastra at Serongga Village in Kotabaru were 1,271 (sampling point 1), 0,974 (sampling point 2), and 1,471 (sampling point 3).

- The water qualities of coal specific port area of PT. Adiabara Bansastra at Serongga Village in Kotabaru according to the criterion of Lee, et al (1978) were moderately polluted (sampling points 1 and 3) and heavy polluted (sampling point 2 ).

- The leaflet was declared valid by validator and can be used for teaching-learning of students.

\section{REFERENCES}

[1] A.T. Sastrawijaya, Pencemaran Lingkungan. Rineka Cipta, Jakarta: 2000.

[2] M.F. Fachrul, Metode Sampling Biologi. Bumi Aksara, Jakarta: 2007.

[3] H. Surbakti, and R. Aryawati, "Komposisi dan Kelimpahan Fitoplankton di Perairan Sekitar Pulau Maspari, Ogan Komering Ilir," Maspari Journal, vol.6, no.1, pp.39-45, 2014.

[4] B. Halang, Keanenakaragaman fitoplankton pada Area Perairan Pelabuhan Khusus Batubara PT.Adiabara Bansastra di Desa Serongga Kabupaten Kotabaru, Banjarmasin: FKIP-ULM, 2018.

[5] J. Lyons, A Fish-Based Index of Biotic Integrity To Assess Intermittent Headwater Streams In Wisconsin, USA. Environ. Monit. and Assess, pp. 239-258, 2006.

[6] D. Djumanto, N. Probosunu, and R. Ifriansyah, "Indek biotik famili sebagai indikator kualitas air sungai gajahwong yogyakarta," Jurnal Perikanan Universitas Gadjah Mada, vol.15, no.1, pp. 26-34, 2013.

[7] E. Aparicio, G. Carmona-Catot, P. B. Moyle, and E. García-Berthou, "Development and evaluation of a fish-based index to assess biological integrity of Mediterranean streams,"Aquatic Conservation: Marine and Freshwater Ecosystems, vol. 21, no.4, pp. 324-337, 2011.

[8] L. Li, J. Xiong, B. Xiao, L. Song, and Z. Xie, "Dynamics of macrozoobenthos assemblages in the Fubao Bay of Lake Dianchi and their relation to organic pollutants," African Journal of Biotechnology, vol. 11, no.55, pp.11830-11837, 2012.

[9] V. P. Campaner, W. Luiz-Silva, and W. Machado, "Geochemistry of acid mine drainage from a coal mining area and processes controlling metal attenuation in stream waters, southern Brazil," Anais da Academia Brasileira de Ciências, vol. 86, no.2, pp. 539-554, 2014.

[10] P. K. Weber-Scannell, and L. K. Duffy, "Effects of total dissolved solids on aquatic organism: a review of literature and recommendation for salmonid species," In American Journal of Environmental Sciences, 2007.

[11] D. Hidayat, R. Suprianto, and P. S. Dewi, "Penentuan kandungan zat padat (total dissolve solid dan total suspended solid) di perairan teluk lampung,"Analit: Analytical and Environmental Chemistry, vol. 1, no.1, 2016. 